MM. Fedynski and Stanjukowitsch) it appears that the velocity decreases by 37 per cent as the meteor falls from $90 \mathrm{~km}$. to $55 \mathrm{~km}$. in height. The same group of observers conducts observations of meteor spectra with a prismatic camera; forty-seven lines were recognised by $M$. Fedynski in a meteor of stellar magnitude -3 , of which the strongest were those of ionised calcium. A third exposure, made in a camera distant $1.5 \mathrm{~km}$., enables the observers to compute the height of the meteor at any point on its illuminated path.

\section{A Naked-Eye Sunspot}

A GROUP of sunspots, large enough to be seen with the naked eye, has been in transit across the sun's disk (Nov. 3-15), in solar latitude $29^{\circ}$ south; the time of central meridian passage was Nov. $9 \cdot 5$. The group, which was of 'stream' or 'bipolar' type, consisted of a very large circular spot with smaller followers. The leader, with an area of 800 millionths of the sun's hemisphere ( 800 millionths = nearly 950 million square miles), was the largest single spot observed since February 1931; the maximum total area of the present group was 1,200 millionths of the sun's hemisphere. On the few occasions when the weather permitted spectroscopic observations to be made at Greenwich, the group was not unusually active. Observations made on Nov. 9-11 show another large stream of spots extending in longitude for nearly 80,000 miles in lat. $21^{\circ}$ north. The time of central meridian passage was Nov. 13·3. During the last two or three months there has been a marked increase in the sun's general activity, as shown by the increased frequency of spots-mainly of small or moderate size-dark and bright hydrogen and calcium markings on the disk and prominences at the edge of the disk.

\section{Announcements}

THE following have been electea as officers of the Cambridge Philosophical Society for 1935-36. President : Dr. F. W. Aston; Vice-Presidents : Prof. A. Hutchinson, Dr. E. D. Adrian, Sir J. Barcroft; Treasurer: Mr. F. A. Potts ; Secretaries: Mr. F. P. White, Dr. J. D. Cockeroft, Dr. H. Hamshaw Thomas. New Members of the Council: Mr. R. A. Hayos, Dr. F. Kidd, Sir G. P. Lenox-Conyngham, Dr. R. G. W. Norrish.

The fifth German Congress of the Scientific Associations on Corrosion will be held in Berlin on November 18-19. The theme of the Congress will be "The Corrosion of Metallic Materials of Construction by Cold Water". Further information can be obtained from the Verein deutscher Chemiker, Berlin W 35, Potsdamer Str. 103a.

Mr. Cyril C. Barnard, librarian of the London School of Hygiene and Tropical Medicine, Keppel Street, W.C.I, informs us that, in view of the numerous requests he has received for a copy of the classification used by him at that Library, he is considering the issue of a small edition in the form of a cloth-bound volume of 144 pp., royal 8vo., at $10 s .6 d$., containing not only the schedules of the classification but also a full explanatory introduetion, local list, index of parasites, and alphabetical subject index. Mr. Barnard can only undertake publication if sufficient promises of support are fortheoming.

THE following appointments have recently been made by the Secretary of State for the Colonies : F. J. Pound, to be agronomist, Department of Agriculture, Trinidad; N. H. Sands, to be agricultural officer, Malaya; F. W. Toovey, to be botanist, Department of Agriculture, Nigeria; W. E. Miller Logan, to be assistant conservator of forests, Gold Coast; A. C. Russell, to be assistant conservator of forests, Gold Coast ; T. N. Wardrop, to be assistant conservator of forests, Nigeria ; J. B. Alexander, to be geologist, Nyasaland; A. Cawley, to be engineering geologist, Tanganyika; W. H. Reeve, to be assistant field geologist, Tanganyika; B. N. Tem. perley, to be assistant field geologist, Tanganyika; W. J. B. Johnson, to be canning officer, Department of Agriculture, Malaya; A. A. Abraham, assistant agricultural superintendent, to be agricultural superintendent, British Guiana; G. W. Lines, late superintendent of agriculture, to be superintendent of agriculture, Nigeria; T. H. Marshall, senior agricultural assistant, to be district agricultural officer, Tanganyika; R. J. M. Swynnerton, agricultural assistant, to be district agricultural officer, Tan. ganyika.

THE Council of the Institution of Civil Engineers has decided that, in future, the Press can attend and report the discussions at any of the ordinary meetings of the Institution. Abstracts or advance copies of the papers to be read are available on application to the Secretary.

Messrs. Edward Arnold and Co. announce the early publication of a new edition of "The Structure of the Alps" by Prof. Leon W. Collet, of Geneva; and also "The Oyster and the Oyster Fishery" by Prof. J. H. Orton, of the University of Liverpool, embodying the Buckland Lectures for 1935.

Applications are invited for the following appoint. ments, on or before the dates mentioned :

An assistant to the research chemist of the London Shellac Research Bureau-The High Commissionerfor India, General Department, India House, Aldwych, W.C.2 (Nov. 26).

An assistant lecturer and demonstrator in physics. in the University of Leeds-The Registrar (Nov. 26).

A pomologist to the Royal Horticultural SocietyThe Secretary, Royal Horticultural Society, Vincent Square, Westminster, S.W.1 (Nov. 30).

A lecturer in geography and education in the University of Dublin-The Registrar (Dec. 2).

A professor of mining in the University of Edinburgh and Heriot-Watt College-The Secretary of the University (Dec. 31).

An assistant master to teach engineering in the Dover Technical Institute-The Principal. 